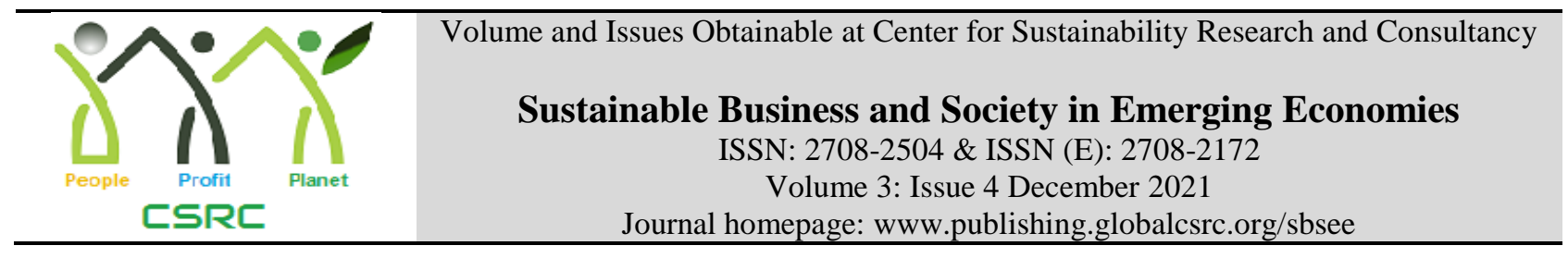

\title{
Engaged Versus Workaholic Employees Job Crafting Behavior: The Moderating Role of Perceived Organization Support
}

*Sadia Ishaque, Ph.D. Scholar, Bahauddin Zakariya University, Multan, Pakistan

Khawaja Khalid Mehmood, Assistant Professor, Bahauddin Zakariya University, Multan, Pakistan

*Corresponding author's email address: sadia.ishaque@ aumc.edu.pk

\section{History}

Revised format: Nov 2021

Available Online: Dec 2021

Keywords

Work engagement, Work

holism, Job Crafting

Behavior, Perceived

Organizational Support.

JEL Classification

D39, J29
Purpose: Making jobs challenging and interesting is becoming a new trend in organizations and is related to job crafting behavior. Employees with different sort of wellbeing predict diverse crafting behaviors. This study is about making comparisons between the two states of wellbeing that can be differentiated on theoretical backgrounds: work engagement and work holism. Specifically, both well beings may differently predict job crafting behavior

Design/Methodology/Approach: This study was quantitative in nature and applied on a sample of 285 faculty members working in higher education institutions in Pakistan. Further, the moderating effect of perceived organizational support was tested by using the SEMAMOS.

Findings: The findings revealed that engaged employees always craft their jobs even if they don't perceive considerable support from their organizations. But the employees who are workaholic, do not usually craft their jobs, but adopt job crafting behavior when they perceive an organizational support.

Implications/Originality/Value: This study points towards an important theoretical connection between employee wellbeing and job crafting behavior. It concludes that employee wellbeing is essential for job crafting and, specifically, for workaholic employees, perceived organizational support is also important.

(C) 2021 The authors, under a Creative Commons AttributionNonCommercial- 4.0

\section{Recommended citation: Ishaque, S. \& Mehmood. K. K. (2021). Engaged Versus Workaholic} Employees Job Crafting Behavior: The Moderating Role of Perceived Organization Support . Sustainable Business and Society in Emerging Economies, 3 (4), 591-603.

\section{Introduction}

A well-known quote is "Happy workforce is productive workforce". Now a days, the research on employee wellbeing is getting more popularity (Ferreira, de Carvalho Chinelato, \& Mendonça, 2022). Organizations are taking keen interest on employee wellbeing to keep their workers happy and motivated. Higher employee wellbeing is important because employees contribute to the bottom line objectives (Demerouti \& Bakker, 2011). The other challenge that organizations are facing is about the dynamic and challenging environment, so to cope with this challenge organizations are giving more autonomy to their employees. One of the outcome of this autonomy is the employees' job crafting behavior that they are adopting to make their task more interesting and challenging (Vakola, Petrou, \& 
Katsaros, 2021). According to circumflex model by (Russell, 1980), there are two dimensions of wellbeing, one is pleasure that is about how one is feelings, and the other is activation. Work engagement and work holism both are high in activation but the state of pleasure is different. Engaged workers are high in pleasure but on other hand workaholic are low in pleasure state. Work engagement indicates a positive affect and favorable results, on the other hand, work holism indicates some negative outcomes (Bakker, Demerouti, Oerlemans, \& Sonnentag, 2013). Work engagement can be explained as an employee's dedication, vigor and absorption at work. Employees are full of energy and enthusiasm and work hard at their work place because they like to do work. (Bakker, Schaufeli, Leiter, \& Taris, 2008). Whereas, work holism can be conceptualized as "compulsion or the uncontrollable need for working incessantly" (Oates, 1971, p. 11). The workaholic people are addicted to work hard; it is just like the alcohol addiction, and that exaggerated work could even effect their mental and physical health (Gorgievski, Bakker, \& Schaufeli, 2010).

According to Hakanen, Seppälä, and Peeters (2017), the employees sense of feeling (pleasant or unpleasant) about the organization may also have an impact on their behaviors. Perceived organizational support is about employees' observation about their organization, that to what degree the organization will esteem their engagement and care about their prosperity (Eisenberger, Cummings, Armeli, \& Lynch, 1997). The present study makes contribution towards the existing literature in following ways. First, it provides a comparison among the two forms of wellbeing i.e. work engagement and work holism in terms of whether employees who are more workaholic are more prone towards the job crafting behavior or it is the other type who are high in job engagement that do more job crafting. Secondly, the study tests the moderating effect of perceived organizational support on these two employees well-being and their job crafting behavior and makes a comparison that how perceived organizational support could change the behavior of these two types of employees.

The job description of faculty members working in higher education is not just limited to teaching, rather there are some additional duties e.g. research and administrative work. In their research activities they not only have to publish work in good journals but also have to supervise students. Furthermore, the faculty promotion is based on the number of publications besides others, so to meet the criteria set by the Higher Education Commission (HEC) they have to work harder which affects their wellbeing. Just because of such variant job responsibilities, this is important to give liberty to faculty, so they could craft their job for their better performance and wellbeing (Khan, Khan, \& Imran, 2018). There are numerous studies in Pakistan, where the focus is faculty wellbeing i.e. job burnout, job satisfaction (Malik \& Björkqvist, 2021; Jahangir, Khorakian, \& Lagzian, 2022). Very less work is found on other two dimensions of well beings i.e. work engagement and work holism, as well as their relationship with job crafting behavior. Hence, this study pays a genuine contribution to research by studying these relationships in the Pakistan context. Faculty members require more organizational support to perform their jobs accordingly. They have to do something new and challenging to meet the criteria set by HEC in Pakistan. They also require feedback and support from their supervisors. So, for the present study the faculty members tend to be the most suitable population. The studies are too limited in the context of Pakistan as far as this subject is concerned. So, this study will also attempt to fill contextual gaps highlighted.

\section{Literature review}

\section{Work engagement}

Work engagement is normally conceptualized as an optimistic and productive psychological state of mind relating to work, marked by absorption, vigor and dedication. Engaged employees are highly energetic (vigor), devoted to their job (dedication), and are intensely and cheerfully involved in their job activities (absorption) (Bakker et al., 2008). The term work engagement was firstly coined by (Kahn, 1990) which could be defined as a positive state of mind at workplace. Engaged employees utilize and communicate intellectually, physically, and genuinely while performing their role. Engagement is characterized as a positive perspective, full contribution in work portrayed by enthusiasm, dedication, 
and assimilation of work (Côté, Lauzier, \& Stinglhamber, 2021).Work engagement mirrors the vitality of employees brought to work; they feel energized as well as excited about utilizing their vitality in their work (Jahangir et al., 2022)

\section{Work holism}

The term work holism was authored in 1971 by Oates who depicted work holism as an instinct and a strong need to work relentlessly. From that point forward, investigation on work holism has been tormented by differences encompassing how to characterize and quantify it. For instance, work holism has been characterized as a dependence on work, pathology, a standard of conduct that perseveres over various hierarchical settings and a disorder containing high drive, high work inclusion and low work satisfaction. It's about the feeling constrained to work as a result of inside pressures, having steady contemplations about work, when not working. The combined group of research bolsters that work holism has negative results. As discoveries overwhelmingly show that work holism is related with negative results for the person even just to get recognition they do not even try to make their work interesting and challenging (Gopika, Wilson, \& Subha, 2021).

\section{Job crafting}

The conceptualization of job crafting is established on the resource based approach. It is characterized as innovations driven by employees on their daily job activities (Ferreira et al., 2022). It came up with three forms of job crafting; expanding job resources by looking out for social support and help, expanding challenging job demands by initiating more projects, diminishing obstructing demands such as maintaining a distance from demanding clients (Petrou, Demerouti, Peeters, Schaufeli, \& Hetland, 2012; Tims, Bakker, \& Derks, 2012). Job crafting motives are attached to workers ability to adjust their levels of job resources and employment demands with their own capacities and inclinations (Tims \& Bakker, 2010). The concept of job crafting is constructed on JD-R (job demands-resources) model according to which individuals craft their jobs on the bases of the job demands and resources (Tims, Arnold, \& Derks, 2014).

\section{Work Engagement, Work holism, and Job Crafting}

The potential outcomes of engagement are certain attitudes toward job and wellbeing, extra-role conduct, and employment performance (Khan, Usman, Saeed, Ali, \& Nisar, 2022). When employees are engaged they may likewise effectively change the substance or structure of their own jobs through job crafting to make their jobs more interesting and engaging for their selves (Tims \& Bakker, 2010).

Regulatory focus theory (Crowe \& Higgins, 1997) states that employees who are engaged have higher level of promotion focus. They more emphasize on their hopes and accomplishments when following their goals. Whereas the workaholic people have the higher levels of prevention focus and they more emphasize on safety, responsibilities, and loss avoidance. So based on this, it is expected that employees having greater degree of promotion focus exhibit higher degree of crafting behavior as compared to the ones with a lower degree of promotion focus. Further, this is argued that employees having greater degree of prevention focus would often indulge in decreasing the hindering demands (which is about avoiding emotional and mental demands associated with a job) and would indulge less in the other forms of job crafting as compared to ones with lower degree of prevention focus. Scholars suggest that generally employees with greater degree of promotion focus have higher probability to take initiatives for improving their person-job fit, while employees having greater degree of prevention focus are rather oriented towards avoiding negative outcomes (such as negative evaluations, low performance) by lowering the job's hindering demands (Bipp \& Demerouti, 2015; Petrou et al., 2012; Wang, Demerouti, $\&$ Le Blanc, 2017). Previous studies showed that engaged employees are more concerned about the job demands and job resources. Furthermore, when employees are engaged they try to make their jobs more challenging and add new and creative tasks to avoid boredom and monotony from their jobs (Tims et al., 2012). Moreover engaged employees ask for more structural and social resources; for example, trying to involve in new things or projects and asking supervisors for feedback and appraisals (Schaufeli \& 
Bakker, 2004). Previous studies show that engaged employees are not inclined towards decreasing hindering demand (that is avoiding the emotional interaction with customer as well as not being involved in cognitive task), whereas according to different studies engaged employees are those who like cognitive tasks, try to solve customer problems in friendly ways and like the emotional interactions associated with a job (Demerouti \& Bakker, 2011; Tims et al., 2012).

Work holic employees are those who work hard without any thinking that either they may succeed or fail in their work on the expense of their health and families (Seppälä et al., 2015). As discussed before there are limited studies on work holism and job crafting, however according to (Schaufeli, Taris, \& Van Rhenen, 2008) workaholic employees can be categorized on the basis of self imposed demands so they also try to make their work more challanging and try to invest their efforts on new projects. So it could be expected that they are also prone towards increasing challanging and structuring demands. Hence, based on these arguments it could be hypothesized that:

H1: Engaged employees are inclined towards job crafting.

H2: Workaholic employees are inclined towards job crafting.

\section{Perceived organizational support}

Perceived organizational support (POS) is dealt as a moderator in this study. POS can be explained as the employees perceptions about their organization that to what extent the organization values their inputs and shows care for their wellbeing (Eisenberger et al., 1997; Oubibi, Fute, Xiao, Sun, \& Zhou, 2022). This is the common thinking found among employees that when orgaization is ready to apraise and support employees, they will work more and help organization to meet their objectives. Now a days, contemporary organizations want such employees who are phychologicaly connected to the work, who are willing to invest their full efforts in their roles, and are proactive and willing to work beyond their job descriptions. Employees who are energetic and fully comitted to high quality performance satandards are in demand. When an employee who is hard working and dedicated to his work feels that his organization will support his cognitive and emotional attachment to his job, he will be more propeled towards job crafting (Côté et al., 2021). So based on these arguments it can be conceptulized that POS can work as an moderator for employee well being (work engagment and work holism) and job crafting behaviour.

Organizational support theory states that the employees get motivated and become more engaged in their jobs when they feel that the organization will care about their well being and appreciate them in term of praise, organizational support, and rewards (Eisenberger et al., 1997; El-Din \& Al-kiyumi, 2022). According to Job Demand Model and theory of the positive psychologists, it is theorized that perceived organiztional support motivates employees to remain involved with their jobs as well as also help them to adopt the crafting behaviour (Eisenberger, Armeli, Rexwinkel, Lynch, \& Rhoades, 2001; Rhoades \& Eisenberger, 2002; Verčič, 2021). Reasearch on perceived organizational support starts with the opinion that, when organizations are more concerned with their employees then employees also become concerned about their organizations (Verčič, 2021). The employees usually develop a belief that the degree to which organization will value their efforts and care about their well beings, they would behave accordingly. If organization is greatly valuinig their work, they would in response work harder. This belief also depends upon the organization's willingness to give incentives to employees on the basis of their improved work efforts. When perception of greater organizational support is found among the employees then employees will try to improve their performance by adding something challanging in their job tasks, would ask for more feedback from their supervisors and try to become more creative in their activities. As discussed before, engaged employees are those who do not decrease the hindering demands associated with jobs which is one form of job crafting (Oubibi et al., 2022). When employees perceive a support from the organization they try to add more challenges at their job and also avoid such job demands which have some negative effects (Putri, Zulkarnain, \& Adnans, 2021). So based on this it can be hypothesized that:

H3: Engaged employees show more job crafting behavior with the moderating role of perceived 
organizational support.

Previous research shows that there are number of factors that make an employee workaholic which might be the personal characteristics of a person or the organiztional values in which he is working (Cossin, Thaon, \& Lalanne, 2021; Spence \& Robbins, 1992; Yilmaz, Yalcin, Kilic, \& Ülbeği, 2021). Most of the researchers state in their work that organizations have visible role in the development and maintainace of workaholic behaviour (Santos, Sousa, Gonçalves, \& Sousa, 2022). It has been noted before that worholic employees are those who work hard to meet the organizational goal. They are those people who are motivated through the introjected motivation, which is adopting the ideas of others without fully knowing them (Van Beek, Hu, Schaufeli, Taris, \& Schreurs, 2012). When workaholic people perceive support from the organization in terms of rewards, they work more hard to achieve the rewards promised by the organization. As discussed earlier, job crafting attitude is also found in workaholic employees; they also add new challenges to their work and also demand increase in structural resources just like the engaged employees to meet the organizational goals. But the workaholic employees are not inclined towards the social resourses, they do not want to help others and even do not want to seek help from others, they just want to achieve the goal for status gain and the rewards promised by their organization. Further, they are oriented more towards decreasing hindering demands, that is avoiding the emotionaly demanding customers and mental demands associated with the job. This type of job demands (hinderances) have a negitive effect on the employees as compared to the other type of challanging job demands, which have the positive effect (Gorgievski \& Bakker, 2010). Uptill now, there are very limited studies concerning relationship of work holism, job crafting and perceived organizational support. So, based on the arguments about POS which suggest that when workaholic employee perceive a support from organization in term of rewards, they work hard to get these rewards and become more inclined towards increasing structural and challanging demands. But this is also found in literature that, workaholic employees are not inclined towards incresing social resource even when an organizational support is there (Harpaz \& Snir, 2003; Spence, 1992). Studies also show that workaholic employees always try to avoid the situation of mental and emotional needs associated with a job even when an organizational support is there (Shahsavandi \& Moosavi, 2021). Employees also demand that organizations must care about their well beings (which may be the work engagment, work holism, burn out, or job satisfaction) (Kurtessis, 2017). Hence, based on these aurguments it can be hypothesized that: H4: Workaholic employees show more job crafting behavior with the moderating role of perceived organizational support.

\section{Methodology \\ Participants}

This study was conducted for the faculty members working in higher educational institutions in Pakistan. Higher education institutions provide tertiary education and are responsible to award an academic degree. There are total 26 private universities and 36 public sector universities in the province Punjab according to the information available through formal HEC, Pakistan website. Stratified sampling technique was used for selecting the universities. Initially, the universities were divided into two strata i.e. public and private universities of Punjab, then further simple random sampling was used to select the universities for data collection. Five universities were selected from the private sector and seven from the public sector universities. A total of 285 responses, 129 from private and 156 from public universities were acquired by using a self-administered questionnaire. The sample of 285 individuals consisted of 168 male respondents and 115 female ones (59\%, 40\% respectively). Concerning respondents' age, $10.5 \%$ of the faculty members were between the age range of $20-30$ years, $51 \%$ were between 31-40 years of age, $20.4 \%$ were between the range of 41-50 years of age, and only $17 \%$ faculty was above the age of 50 years. When inquired about qualification, $36 \%$ of the faculty were MPhil and 63\% were having $\mathrm{PhD}$ qualification. 
Measures

\section{Work Engagement}

Utrecht WE Scale by Schaufeli, Bakker, and Salanova (2006) was employed in this research for measurement of work engagement. It has three dimensions i.e. vigor, dedication, and absorption. Some of the items used were, for example, "At my work, I feel bursting with energy (vigor), "I feel happy when I am working intensely" (absorption), "I am enthusiastic about my job" (dedication). There were nine items scaled for a 5-point scale (Likert type).

\section{Work holism}

Dutch Work holism Scale by Schaufeli, Shimazu, and Taris (2009) was used for the assessment of workaholic people. It has two dimensions: one is working excessively (e.g., "I seem to be in a hurry and racing against the clock") and the other is working compulsively (e.g., "It is important for me to work hard even when I do not enjoy what I am doing"). The scale was rated for 4 point scale from 1(almost never) to 4(almost always).

\section{Job Crafting}

For this construct, the scale by Tims et al. (2012) was utilized. It was based on three dimensions i.e. expanding social resources (e.g. "I ask my supervisor to coach me"), expanding challenging demands (e.g. "When an interesting project comes along, I offer myself proactively as project co-worker") and decreasing hindering resources(e.g. "make sure that my work is mentally less intense"). These dimensions were assessed on 5 point scale as well.

\section{Perceived Organizational Support}

For POS, a shorter version of 8 item scale was adopted from (Eisenberger et al., 1997). Previously the scale was available for 36 items but we used the 8 item scale (e.g. "The organization values my contribution to its well-being") following the recommendations of Rhoades and Eisenberger (2002). Since the original scale was one dimensional and highly reliable that's why using short version did not make any problem.

\section{Data analysis and results}

AMOS-SEM was used for the data analyses with SPSS which is a covariance based approach. For SEM, there are some assumptions that must be tested to run the analyses. The first assumption is the test of normality. We used AMOS to test the multivariate normality. In normality test, the critical value is matched with the 5 percent level of (which is equal to 1.96) the standardized normal distribution( $\mathrm{Z})(\mathrm{Cox}$ \& Small, 1978; Korkmaz, Göksülük, \& Zararsiz, 2014). If the value is equal to or lower than the above mentioned threshold level, the normality is achieved. In the analysis performed on the data, the absolute value of CR(1.85) was less than 1.96, so the first assumption of the multivariate normality was met. The second assumption was about the test of outliers. For this, Mahalanobis distance(Md) test was run and no outlier was found. Further, the third assumption regarding linearity was met by using Ramsey reset test as shown in table 1 (Fernandes, Budiantara, \& Otok, 2015).

Table 1: Linearity assumption test

\begin{tabular}{llc}
\hline Effect & Result of Ramsey Test & Conclusion \\
\hline Work engagement on job crafting & p-value $=0.022<0.05$ & Linear \\
Work holism on job crafting & p-value $=0.011<0.05$ & Linear \\
\hline
\end{tabular}

\section{Goodness of fit}

Model fitness tells proposed model fitness that how much correlation is present among variables. If the fit indices are not between the standard threshold, then the model is not accepted (Gefen, Straub, \& Boudreau, 2000). Fit indices that describe the fitness of measurement model have different types (they are shown in table 2). These indices help in observing the measurement model fitness (Schreiber, Nora, Stage, Barlow, \& King, 2006). The first measurement model was comprised of four latent variables with 
forty three observed variables. The nine above stated fit indices were used to account the results according to an assured tolerable criteria. When the first measurement model was run, the values of the fit indices of the proposed model did not meet with the specified criteria.

It could be noticed in table 2, initially for the first measurement model, mostly the fit indices were according to the standard threshold level. $\mathrm{CMIN} / \mathrm{DF}=1.742, \mathrm{GFI}=.746, \mathrm{AGFI}=.724, \mathrm{NFI}=.786, \mathrm{CFI}$ $=.885, \mathrm{IFI}=.886, \mathrm{PCLOSE}=.060$ and RMSEA $=.053$. But some of the indices were poor fit and implied no data fit with the theorized model. So it needed some re-specifications and improvements. The model re-specification was required to improve the model fitness. During the process of model respecification 10 items out of 43 were removed since their factor loadings were less than 0.07 threshold level (Shek \& Yu, 2014) and 33 items were retained. After the model re specification model goodness of fit was achieved.

\begin{tabular}{|c|c|c|c|}
\hline Sr. & $\begin{array}{l}\text { Goodness of fit } \\
\text { indices }\end{array}$ & $\begin{array}{l}\text { Initial } \\
\text { Model }\end{array}$ & $\begin{array}{c}\text { Re- } \\
\text { specified } \\
\text { Model }\end{array}$ \\
\hline 1 & $\begin{array}{l}\text { Relative-Chi } \\
\text { square } \\
\text { (CMIN/DF) }\end{array}$ & $\begin{array}{c}1.742 \\
\text { good } \\
\text { Fit }\end{array}$ & 1.451 \\
\hline 2 & $\begin{array}{l}\text { GFI-Goodness of } \\
\text { Fit Index }\end{array}$ & $\begin{array}{c}.746 \\
\text { Poor } \\
\text { Fit }\end{array}$ & .946 \\
\hline 3 & $\begin{array}{l}\text { AGFI-Adjusted } \\
\text { GFI }\end{array}$ & $\begin{array}{c}.724 \\
\text { Poor } \\
\text { Fit }\end{array}$ & .924 \\
\hline 4 & $\begin{array}{l}\text { CFI- } \\
\text { Comparative Fit } \\
\text { Index }\end{array}$ & $\begin{array}{c}.885 \\
\text { Poor } \\
\text { Fit }\end{array}$ & .943 \\
\hline 5 & $\begin{array}{l}\text { RMSEA- Root } \\
\text { Mean Square } \\
\text { Error of } \\
\text { Approximation }\end{array}$ & $\begin{array}{c}.053 \\
\text { GF }\end{array}$ & .042 \\
\hline 6 & $\begin{array}{l}\text { NFI-Normed Fit } \\
\text { Index }\end{array}$ & $\begin{array}{c}.786 \\
\mathrm{PF}\end{array}$ & .988 \\
\hline 7 & $\begin{array}{l}\text { IFI-Incremental } \\
\text { Fit Index }\end{array}$ & .886 & .943 \\
\hline 8 & PCLOSE & .060 & .998 \\
\hline
\end{tabular}

Another part of analysis was testing of structural models as they reveal the nature and significance of the relationships among the constructs. The coefficients in the model explain the magnitude of relationship 
among constructs. For a 95\% confidence level, a significant impact of one variable over another is assumed if its $\mathrm{p}$-value is less than 0.05 . For the structural model tests, moderation analysis were run separately for work engagement and work holism. Initially, the impact of work engagement and work holism was analyzed on job crafting behavior. The findings for that are provided in Table 3. Afterwards, the moderating role of perceived organizational support was investigated for the relationships. For the analyses, the z-scores of the independent and moderator variables were used in order to avoid multicollinearity problems. The findings for that are provided in Table 4 and figure 1a, $1 \mathrm{~b}$.

Table 3: Findings for the Impact of Work Engagement and Work holism on Job Crafting

\begin{tabular}{|c|c|c|c|c|c|}
\hline Relationship & Estimate & S.E. & C.R. & p-value & Conclusion \\
\hline $\begin{array}{l}\text { H1.Engaged employees are inclined towards job crafting. } \\
\text { (WE } \rightarrow \text { JC) }\end{array}$ & 0.139 & 0.024 & 5.806 & .000 & significant \\
\hline $\begin{array}{l}\text { H2. Workaholic employees are inclined towards job } \\
\text { crafting. }(\mathrm{WH} \rightarrow \mathrm{JC})\end{array}$ & 0.567 & 0.027 & -0.492 & .623 & Not significant \\
\hline
\end{tabular}

From the above test results, it can be concluded that hypothesis $\mathrm{H} 1(\mathrm{CR}=5.806, \mathrm{p}=0.000)$ that is engaged employees are more inclined towards job crafting behavior is significant but the second hypothesis that workaholic employees are more inclined towards job crafting $(\mathrm{CR}=-0.492, \mathrm{p}=.623)$ was not accepted. Further, positive estimate for H1 (0.139) implies that as work engagement increases, it leads to more job crafting behavior. In the next stage, the moderation test was run by taking perceived organizational support as a moderator.

An interaction effect for the moderating effect on the dependent variable (job crafting) was created. The test results of moderation are presented in Figure 1a, 1b and Table 4. For H3 (regarding moderating effect of POS for the relationship between work engagement and job crafting) the results revealed significant moderating effect with p-value of 0.0006 , therefore $\mathrm{H} 3$ was accepted. However, for H3, POS should be treated as a quasi-moderator since the relationship between POS and JC was also found significant $(C . R=6.310, p=0.000$, Estimate $=0.154)$.

\begin{tabular}{|c|c|c|c|c|c|}
\hline Relationship & Estimate & S.E. & C.R. & p-value & Conclusion \\
\hline $\begin{array}{l}\text { H3. Engaged employees are more inclined } \\
\text { towards job crafting with the moderating role } \\
\text { of POS. (WEXPOS } \rightarrow J C)\end{array}$ & 0.127 & 0.045 & .242 & 0.0006 & significant \\
\hline $\begin{array}{l}\text { H4. Workaholic employees are more inclined } \\
\text { towards job crafting with the moderating role } \\
\text { of POS. (WHxPOS } \rightarrow \mathrm{JC} \text { ) }\end{array}$ & 0.139 & 0.026 & .196 & .001 & significant \\
\hline
\end{tabular}

Regarding the nature of moderator effect, it can be seen from figure 1a that POS acts as a positive moderator for work engagement (WE) and job crafting (JC) relationship. The graphs available in the figure depict that at higher level of POS, the relationship between work engagement and job crafting is more positive. 


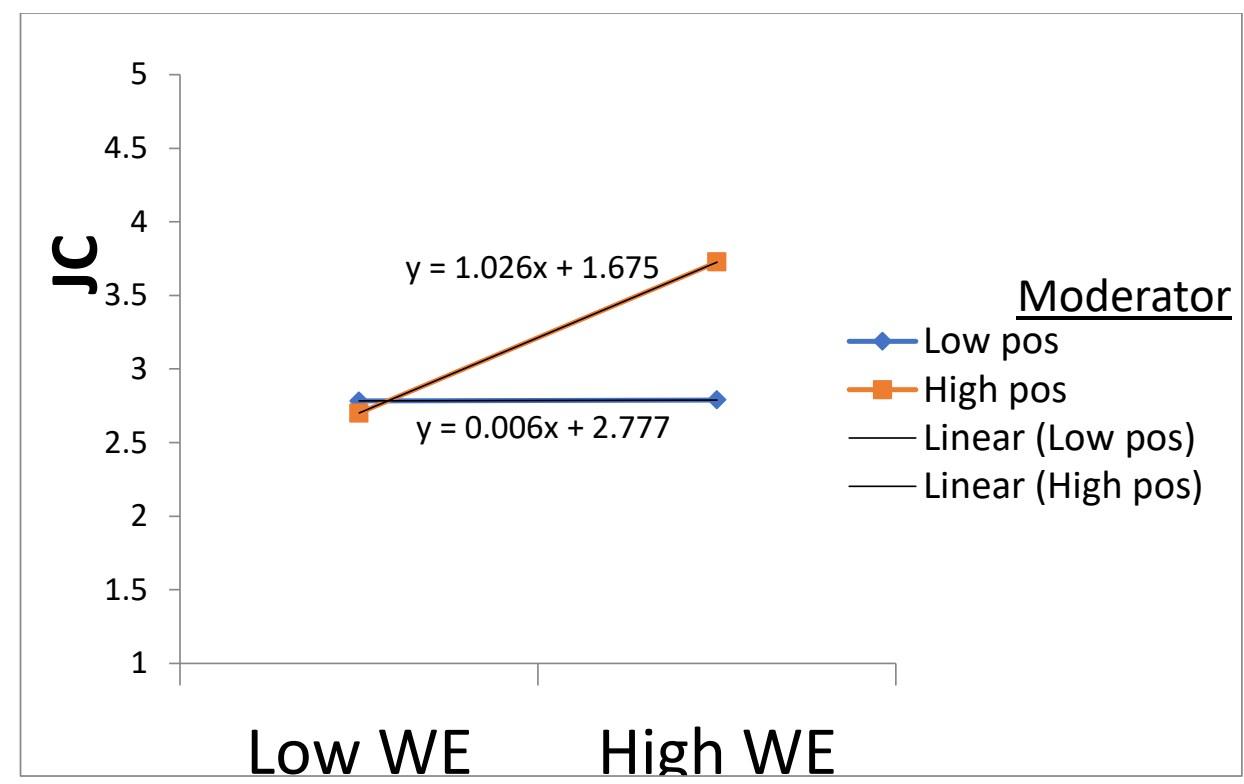

Figure 1a: Moderating Effect of POS for WE and JC Relationship

For H4 (concerning the moderating effect of POS on the relationship between work holism and job crafting behavior), the results (Table 4) revealed a p-value of 0.001 (for the impact of interaction term on job crafting). Thus H4 was accepted. Further, POS should be treated as a quasi-moderator in this case as well since the relationship between POS and JC was also found significant in this model $(\mathrm{C} . \mathrm{R}=5.495, \mathrm{p}$ $=0.000$, Estimate $=0.169$ ). For the nature of moderating effect, Figure $1 \mathrm{~b}$ shows that the relationship between work holism and job crafting is higher at increased level of POS compared to its lower level. Hence, workaholics do more job crafting if they perceive greater degree of perceived organizational support for them.

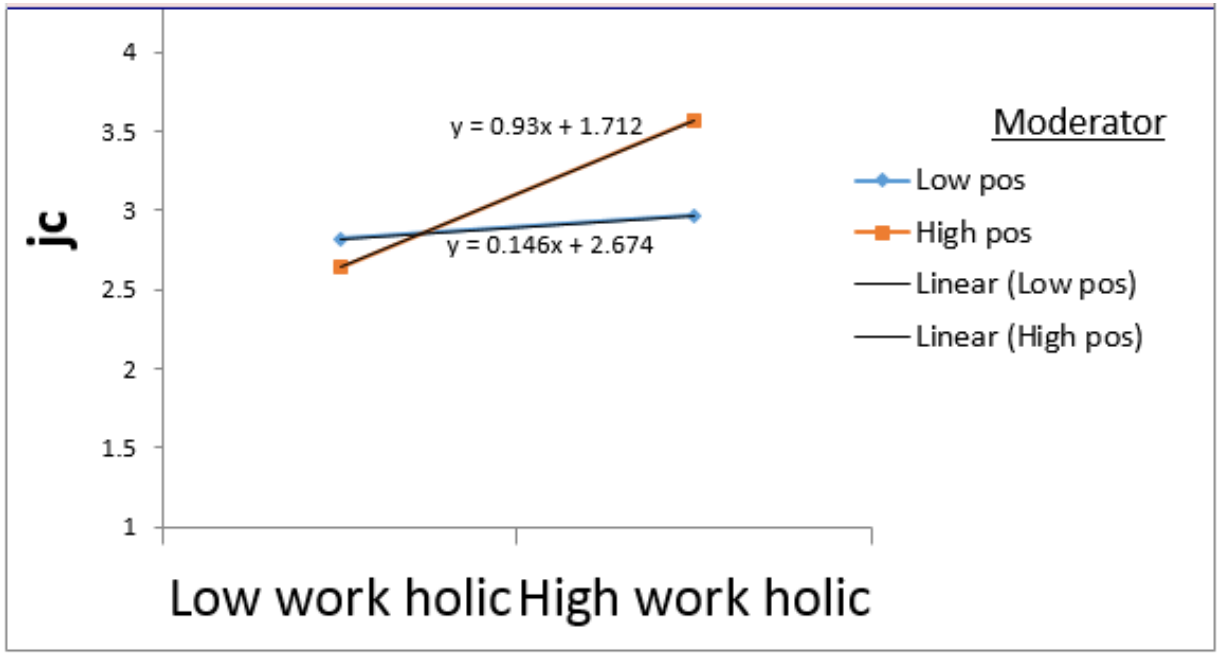

Figure 1b: Moderating Effect of POS for WH and JC Relationship

\section{Discussion, Conclusions, and Recommendations}

The basic purpose of this research was to describe that how two different well beings respond to job crafting behavior in presence of perceived organizational support, and the main findings indicate that POS works as a moderator. While discussing the hypothesis 1 which is about that engaged employees are inclined towards the job crafting behavior is accepted. It is also shown in previous researches that because engaged employees are more dedicated and vigilant that's why they always try to make their work more challenging and interesting and schedule their tasks according to their own styles (Vakola et al., 2021). The second hypothesis was about the workaholic employees and their tendencies towards the job crafting behavior. We have already discussed in the literature that since workaholic employees are 
very much dedicated and want achievements in their life that's why they also craft their assigned tasks in order to get their desired goals (Sharma \& Tolani, 2015). But the job crafting behavior is not just limited to designing the jobs according to your own wish, there are also some other aspects of job crafting like looking for social support, hindering job demands. The workaholic employees no doubt try to craft their jobs but they ignore the other aspects of job crafting. For example they do not want social interaction, they always try to maintain a difference with demanding clients. There are three different forms of job crafting i.e. expanding job resources by looking out for social support and help, expanding challenging job demands by initiating more projects, diminishing obstructing demands such as maintaining a distance from demanding clients (Petrou et al., 2012; Tims et al., 2012). Research shows that no doubt workaholics work hard for their achievements and try to increase challenges in their jobs but they neglect some aspects of the job crafting behavior. For example in job crafting behavior people try to increase their social resources, but workaholic people are very much poor in their social interactions, they are also high in decreasing hindering demands, and always try to maintain a difference from the demanding clients (Bakker et al., 2013). Anyway, the impact of work holism on job crafting needs further research inquiry in various contexts and for other types of jobs as well.

Hypothesis three concerning moderating impact of POS on the relationship between work engagement and job crafting was accepted and the graphs revealed positive nature of moderation. Since H1 was also accepted, so it can be concluded that the employees who are engaged, they always try to craft their jobs even the POS is there or not. But on the other hand, for workaholics, they would only craft their jobs if they perceive high POS from their organizations. They are the people who do not love to craft their jobs, they avoid social interactions. But if they perceive that their organization will always support them in all cases then they will also craft their jobs just like the people who are engaged.

Recommendation for practitioners, especially practitioners of academia (university officials, owners, stakeholders) are that they can take the best advantage from the workaholic people by changing their perception about the organization by showing them support. By this the negative elements that are present in workaholic people can also be avoided by providing high perceived organizational support. This research only collected data from university faculty. Future research could be conducted for other sectors as well and in other contexts. Some other moderators like perceived self-efficacy could also be considered for investigation in these relationships.

\section{References}

Bakker, A.B., Demerouti, E., Oerlemans, W., \& Sonnentag, S. (2013). Workaholism and daily recovery: A day reconstruction study of leisure activities. Journal of Organizational Behavior, 34(1), 87107.

Bakker, A.B., Schaufeli, W.B., Leiter, M.P., \& Taris, T.W. (2008). Work engagement: An emerging concept in occupational health psychology. Work \& Stress, 22(3), 187-200.

Bipp, T., \& Demerouti, E. (2015). Which employees craft their jobs and how? Basic dimensions of personality and employees' job crafting behaviour. Journal of Occupational and Organizational Psychology, 88(4), 631-655.

Cossin, T., Thaon, I., \& Lalanne, L. (2021). Workaholism prevention in occupational medicine: A systematic review. International Journal of Environmental Research and Public Health, 18(13), 7109.

Côté, K., Lauzier, M., \& Stinglhamber, F. (2021). The relationship between presenteeism and job satisfaction: A mediated moderation model using work engagement and perceived organizational support. European Management Journal, 39(2), 270-278.

Cox, D.R., \& Small, N. (1978). Testing multivariate normality. Biometrika, 65(2), 263-272.

Crowe, E., \& Higgins, E.T. (1997). Regulatory focus and strategic inclinations: Promotion and prevention in decision-making. Organizational behavior and human decision processes, 69(2), 117-132. 
Demerouti, E., \& Bakker, A.B. (2011). The job demands-resources model: Challenges for future research. SA Journal of Industrial Psychology, 37(2), 01-09.

Eisenberger, R., Cummings, J., Armeli, S., \& Lynch, P. (1997). Perceived organizational support, discretionary treatment, and job satisfaction. Journal of Applied Psychology, 82(5), 812-820.

Eisenberger, R., Armeli, S., Rexwinkel, B., Lynch, P. D., \& Rhoades, L. (2001). Reciprocation of perceived organizational support. Journal of Applied Psychology, 86(1), 42.

El-Din, N. S. M. S., \& Al-kiyumi, A. R. A. (2022). Perceived organizational support for faculty members at Sultan Qaboos University: A field study. Available at https://jealex.journals.ekb.eg/article_213114_efc4a5447559a3f7f8e450f0d3eca792.pdf

Fernandes, A.A.R., Budiantara, I.N., \& Otok, B.W. (2015). Spline estimator for bi-responses and multipredictors nonparametric regression model in case of longitudinal data. Journal of Mathematics and Statistics, 11(2), 61-69.

Ferreira M.C., de Carvalho Chinelato R.S., Mendonça H. (2022) Job Crafting Measures. In: Macambira M.O., Mendonça H., Paz M..G.T. (eds) Assessing organizational behaviors. Springer, Cham.

Gefen, D., Straub, D., \& Boudreau, M.-C. (2000). Structural equation modeling and regression: Guidelines for research practice. Communications of the Association for Information Systems, $4(1), 7$.

Gopika, M. N., Wilson, M. N. C., \& Subha, K. (2021). A study on employee engagement in IT firms. UGC Care Journal, 44(1), 49-58.

Gorgievski, M.J., \& Bakker, A.B. (2010). Passion for work: Work engagement versus workaholism. In S. Albrecht (Ed.) Handbook of employee engagement, pp. 264-271.

Gorgievski, M.J., Bakker, A.B., \& Schaufeli, W.B. (2010). Work engagement and workaholism: Comparing the self-employed and salaried employees. The Journal of Positive Psychology, 5(1), 83-96.

Hakanen, J.J., Seppälä, P., \& Peeters, M.C. (2017). High job demands, still engaged and not burned out? The role of job crafting. International Journal of Behavioral Medicine, 24(4), 619-627.

Harpaz, I., \& Snir, R. (2003). Workaholism: Its definition and nature. Human Relations, 56(3), 291-319.

Jahangir, M., Khorakian, A., \& Lagzian, M. (2022). The impacts of work engagement on innovative behavior with an emphasis on the mediatory role of sharing mistakes. Innovation Management Journal, 5(1), 29-52.

Kahn, W.A. (1990). Psychological conditions of personal engagement and disengagement at work. Academy of Management Journal, 33(4), 692-724.

Khan, J., Usman, M., Saeed, I., Ali, A., \& Nisar, H. (2022). Does workplace spirituality influence knowledge-sharing behavior and work engagement in work? Trust as a mediator. Management Science Letters, 12(1), 51-66.

Khan, M.M., Khan, E., \& Imran, S.A. (2018). Using job crafting to improve the well-being and faculty performance: The case of higher education institutions of Pakistan. Global Management Journal for Academic \& Corporate Studies, 8(1), 65-77.

Korkmaz, S., Göksülük, D., \& Zararsiz, G. (2014). MVN: An R package for assessing multivariate normality. R Journal, 6(2). 151-162.

Kurtessis, J.N., Eisenberger, R., Ford, M.T., Buffardi, L.C., Stewart, K.A., \& Adis, C.S. (2017). Perceived organizational support: A meta-analytic evaluation of organizational support theory. Journal of Management, 43(6), 1854-1884.

Malik, N.A., \& Björkqvist, K. (2021). An evidence-based framework for reducing occupational stress and burnout in Pakistani Universities. Asian Journal of University Education, 17(1), 19-32.

Oates, W.E. (1971). Confessions of a workaholic: The facts about work addiction: NY: World Publishing Company.

Oubibi, M., Fute, A., Xiao, W., Sun, B., \& Zhou, Y. (2022). Perceived organizational support and career satisfaction among chinese teachers: The mediation effects of job crafting and work engagement during COVID-19. Sustainability, 14(2), 623. 
Petrou, P., Demerouti, E., Peeters, M.C., Schaufeli, W.B., \& Hetland, J. (2012). Crafting a job on a daily basis: Contextual correlates and the link to work engagement. Journal of Organizational Behavior, 33(8), 1120-1141.

Putri, D.R., Zulkarnain, \& Adnans, A.A. (2021). The effect of job crafting on work engagement with perceived organizational support as moderator in bank Sumut head office. International Journal of Multidisciplinary Research and Growth Evaluation, 2(1), 170-177.

Rhoades, L., \& Eisenberger, R. (2002). Perceived organizational support: A review of the literature. Journal of Applied Psychology, 87(4), 698-714.

Russell, J. A. (1980). A circumplex model of affect. Journal of Personality and Social Psychology, 39(6), 1161-1178.

Santos J., Sousa C., Gonçalves G., Sousa A. (2022) Work Passion And Workaholism: Consequences on Burnout Of Health And Non-Health Professionals. In: Arezes P.M. et al. (eds) Occupational and environmental safety and health iii. studies in systems, decision and control, vol 406. Springer, Cham. https://doi.org/10.1007/978-3-030-89617-1_44

Schaufeli, W.B., \& Bakker, A.B. (2004). Job demands, job resources, and their relationship with burnout and engagement: A multi-sample study. Journal of Organizational Behavior, 25(3), 293-315.

Schaufeli, W.B., Bakker, A.B., \& Salanova, M. (2006). The measurement of work engagement with a short questionnaire: A cross-national study. Educational and Psychological Measurement, 66(4), 701-716.

Schaufeli, W.B., Shimazu, A., \& Taris, T.W. (2009). Being driven to work excessively hard: The evaluation of a two-factor measure of workaholism in the Netherlands and Japan. Cross-Cultural Research, 43(4), 320-348.

Schaufeli, W.B., Taris, T.W., \& Van Rhenen, W. (2008). Workaholism, burnout, and work engagement: Three of a kind or three different kinds of employee well-being? Applied Psychology, 57(2), 173203.

Schreiber, J.B., Nora, A., Stage, F.K., Barlow, E.A., \& King, J. (2006). Reporting structural equation modeling and confirmatory factor analysis results: A review. The Journal of Educational Research, 99(6), 323-338.

Seppälä, P., Hakanen, J., Mauno, S., Perhoniemi, R., Tolvanen, A., \& Schaufeli, W. (2015). Stability and change model of job resources and work engagement: A seven-year three-wave follow-up study. European Journal of Work and Organizational Psychology, 24(3), 360-375.

Shahsavandi, P., \& Moosavi, Z. (2021). Predicting the mental health of the staff of an industrial complex based on perceived organizational support, workaholism, and organizational citizenship behavior. Occupational Hygiene and Health Promotion.

Sharma, G., \& Tolani, B. (2015). Subjective well-being for employees in an organization. Indian Journal of Health and Wellbeing, 6(5), 529.

Shek, D.T., \& Yu, L. (2014). Confirmatory factor analysis using AMOS: A demonstration. International Journal on Disability and Human Development, 13(2), 191-204.

Spence, J. T., \& Robbins, A. S. (1992). Workaholism: Definition, measurement, and preliminary results. Journal of personality assessment, 58(1), 160-178.

Tims, M., Arnold, B.B., \& Derks, D. (2014). Daily job crafting and the self-efficacy-performance relationship. Journal of Managerial Psychology, 29(5), 490-507.

Tims, M., \& Bakker, A.B. (2010). Job crafting: Towards a new model of individual job redesign. $S A$ Journal of Industrial Psychology, 36(2), 1-9.

Tims, M., Bakker, A. B., \& Derks, D. (2012). Development and validation of the job crafting scale. Journal of Vocational Behavior, 80(1), 173-186.

Vakola, M., Petrou, P., \& Katsaros, K. (2021). Work engagement and job crafting as conditions of ambivalent employees' adaptation to organizational change. The Journal of Applied Behavioral Science, 57(1), 57-79.

Van Beek, I., Hu, Q., Schaufeli, W.B., Taris, T.W., \& Schreurs, B.H. (2012). For fun, love, or money: What drives workaholic, engaged, and burned-out employees at work? Applied Psychology, 61(1), 30-55. 
Verčič, A.T. (2021). The impact of employee engagement, organisational support and employer branding on internal communication satisfaction. Public Relations Review, 47(1), 102009.

Wang, H.-J., Demerouti, E., \& Le Blanc, P. (2017). Transformational leadership, adaptability, and job crafting: The moderating role of organizational identification. Journal of Vocational Behavior, 100, 185-195.

Yilmaz, S., Yalcin, A., Kilic, K.C., \& Ülbeği, İ.D. (2021). The relationship between workaholism and well-being: The mediating roles of work-family conflict and stress: A study on high school teachers in adana. Çukurova Üniversitesi Sosyal Bilimler Enstitüsü Dergisi, 30(3), 251-265. 